and then creep underneath, when, after running about and exhausting the supply, they fly off to another leaf, exactly as if they were visiting flowers. The leaves of the oaks are clean, and have no "honey-dew" on them.

Highfield, Gainsborough, August 5.

\section{Dredging Products.}

Amongst the products of the dredgings which my friend the Rev. J. H. Crawford and I. are procuring from the Voe here, I am glad to be able to record the presence of Actinotrocha. We only got two or three specimens at first, but to-day a large number was procured from the surface net. One or two have attained to the Phoronis condition since being brought in. They answer in all respects to Actinotrocha branchiata, but seem to be as a rule less pigmented than the specimen found in St. Andrews Bay.

Actinotrocha branchiata has now been found on both sides of Scotland and England, and also at Heligoland; but, besides being got in the North Sea and on the west coast of Britain (vide NATURE, vol. xxxiv.), it seems also to be found on the western side of the Atlantic, for Wilson records it from Chesapeake Bay. It is thus distinctly a northern form, but has a wider distribution than has hitherto been supposed.

Sullom, Northmavine, Shetland, August 4 Alexr. Meek.

\section{THE INTERNATIONAL CONGRESS OF HYGIENE AND DEMOGRAPHY.}

NEVER before, perhaps, in the history of science has there been assembled together such a numerous gathering of eminent men of science of different nationalities, or representing so many countries, for the purpose of discussing scientific problems.

Although it is little to the national credit that the importance of international Conferences on Health was suggested by the Belgians and not by ourselves, the conditions we are under here must not be forgotteñ. All other civilized countries have strongly represented among their Ministers, and among administrators, men of knowledge and competence; and elsewhere such Congresses are treated as of national concern.

Here, even in the matter of health, such powerful and economical methods of obtaining and distributing knowledge, such as Congresses like the present afford, are absulutely ignored by the party politicians to whom we comm it our national welfare.

There can be little doubt that most of the good which is certain to arise from the deliberations now going on must be ascribed to the Queen and Prince of Wales, who came forward as Patron and President of a Congress ignored, as we have said, by our party rulers. This has been pointed out by the St. James's Gazette:- "The Prince of Wales has rendered a not inconsiderable service to his country by good-naturedly pulling the Congress out of the fire, and rendering a partial success of what came near to being a sad fiasco. But for his complaisance in sacrificing his holiday in coming up to London to take the chair, no public personage would have been present to welcome the two or three thousand guests bidden to the metropolis, or to give attraction and dignity to the opening meeting. . . . There are three Ministers whose departments have relation to the subjects treated by the Congress: Mr. Ritchie, who is our quasi-Minister of public health and relief; Mr. Chaplin, whose department deals with the hygiene and prevention of disease of animals; and Lord Cranbrook, who controls medical education. Not one of these Ministers was present yesterday. Not even the Registrar-General, the head of the department of vital statistics, or a representative of the Home Secretary, took part in yesterday's meeting. The Prince, lrowever, saved the positiun."

The devoted and unpaid labours of many eminent men have, however, with this slight touch of sational feeling in high quarters, already rendered the success of the Congress unparalleled, and it is really wonderful to see what they have done, in spite of the enormous difficulty of arranging for a large number of people in such a city as London. Even the facilities afforded by Burlington House and the University of London buildings do not include a hall large enough for an adequate reception room ; at first, therefore, there were difficulties, largely owing to its absence. This will hardly be wondered at, when we state that the numbers enrollec already are about 3000 , and that there are 40 delegates from the German Empire and 70 from India, only to give two instances.

In anticipation of the meeting, among other official documents too numerous tomention, was prepared a Hand-book to London, with special reference to the needs of the members. This is a volume of 250 pages, in French and English, with eight plates showing the position of hospitals, cemeteries, markets, and the like. This has been published by Messrs. Cassell. There is another volume of 233 pages, containing abstracts of the more important papers to be read. Nor have the English Committee been the only workers. We have "Denmark: its Medical Organization, Hygiene, and Demography," with numerous illustrations and maps, published in English by authority of the Danish Government in time for the International Congress. This has been published by Messrs. Churchill.

In spite of the abstentation of any notice on behalf of the Government, it is pleasant to note the way in which the Lord Mayor and the Corporation, the Royal Colleges of Physicians and Surgeons, and numerous other public bodies and private individuals have kept up the credit of the nation for hospitality. Among the conversazioni must be specially mentioned that at the Guildhall on Tuesday evening, when the Lord Mayor received the members of the Congress. It was a brilliant and impressive sight, enhanced by the uniforms of foreign officers, and the unfamiliar garbs of members of our own distant dependencies. The various social arrangements made by the organizing committee are recorded in a special pamphlet of fourteen pages.

The proceedings began on Monday by a meeting in St. James's Hall, presided over by the Prince of Wales. Sir Douglas Galton first presented the Report of the Permanent International Committee, and inter alia gave the following account of the general organization :-

"The work of the Congress has been arranged in two divisions, viz. hygiene and demography, and it has been found necessary to divide the former into nine sections, each under a separate president, and with separate organization. Committees have been organized in foreign countries to further the interests of the Congress in a more direct manner than could be done from England. Delegates have been appointed by all the Governments of Europe, and also by the United States, Mexico, Venezuela, Japan, Persia, Egypt, by the provinces and native states of the Empire of India, by the most important colonies, and also by numerous municipal authorities, universities, scientific and medical societies, and other institutions throughout the world, and large numbers of the most importart authorities on the subjects to be treated of have sent communications to be laid before the Congress."

After the reading of this Report, the Prince of Wales opened the proceedings by a careful and sympathetic address. One part of it referred to the dangers to health inevitable to the conditions under which we live. He remarked in relation to these dangers :-

"It will be no trivial work if their sources and probable remedies can be clearly pointed out, and especially if this can be done, as in a Congress such as this it should be, in a strictly scientific manner, calmly and dispassionately, without any reference to either general or municipal politics, or for any other purpose than the promotion of health. It is only on conviction such as may thus be pro- 